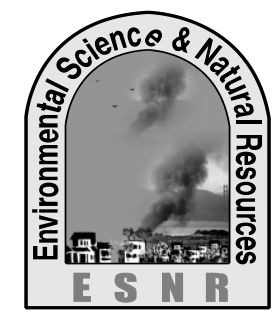

\title{
Physicochemical Composition of the Household Solid Waste and Prospect for Biogas Production
}

\author{
A. B. Thakur ${ }^{1}$, S. Y. Rikta ${ }^{2}$, N. J. Easha ${ }^{1}$, M. A. B. Siddik ${ }^{1}$ and M. K. Uddin ${ }^{1 *}$ \\ ${ }^{1}$ Department of Environmental Sciences, Jahangirnagar University, Savar, Dhaka- 1342 \\ ${ }^{2}$ Department of Environmental Science, Bangladesh University of Professionals, Mirpur, \\ Dhaka-1216 \\ *Corresponding author: khabir88@yahoo.com
}

\begin{abstract}
Solid waste management is now one of the big challenging issues in Bangladesh. With increasing population, volume of solid waste is increasing enormously. Production of biogas from organic solid waste is an environment friendly energy source as well as great management strategy of solid waste. The purpose of this current study is to determine the physicochemical composition of solid waste to determine the prospect of biogas production. Results reveal that, temperature and $\mathrm{pH}$ of the solid waste should be controlled for the maximum production of biogas. On the other hand, collected solid waste samples contained sufficient amount of moisture for the production of biogas. Appropriate temperature controlling system and buffer for $\mathrm{pH}$ maintenance can play a great role to maximize biogas production.
\end{abstract}

Key words: Bangladesh, Biogas, $\mathrm{pH}$, Physicochemical composition, Solid waste and Temperature

\section{Introduction}

During the last two decades, the waste haulage and waste disposal system has undergone considerable importance for maintaining hygiene as well as eco-friendly environment in Bangladesh (Sarker and Uddin, 2013 ${ }^{\mathrm{a}}$ ). In Bangladesh solid wastes make an incredible environmental and social problem in city lives. The urban area of Bangladesh generates approximately 16,015 tons of solid waste per day, which adds up to over 5.84 million tons annually. It is projected that this amount will grow up to 47,000 tons/day and close to 17.16 million tons per year by 2025 , due to growth both in population and the increase in per capita waste generation (Alam et al., 2016).Open dumping; sanitary land filling, incineration and composting are the most prominent disposal methods in various parts of the world (Islam et at., 2015). Biogas provides a solution to organic solid wastes. This is also a sustainable way to meet the global environmental prospective is to reduce environmental degradation and land-based pollution (Sarker and Uddin, 2013 ${ }^{\mathrm{b}}$ ). Using household solid waste as a source is probably one of the most pleasant ways of producing biogas. Put in the simplest way; use of solid wastes as an energy source can be used for different needs and purposes. It can be used for heating, generating electricity or upgrade the gas and use it as a fuel for our vehicles. No doubt this is an important step in sustainability of present societies. Capturing the methane released from the landfills and breaking them down into carbon dioxides by biogas utilization will certainly help reduce greenhouse gas (GHG) emissions, given methane is a 25 times stronger than carbon dioxide in means of greenhouse effect (Curry and Pillay, 2012). The approach of biogas production from household solid waste might help to reduce adverse impact on earth due to climate change (Sarker and Uddin, 2011). It gains even more importance when it is realized that, the amount of waste will be increasing in the future. At present the main energy production in Bangladesh is based on natural gas $(81.43 \%)$. As the demand is increasing and the reserve of the natural gas is decreasing (BPDB, 2008).

The process of biogas production is done by anaerobic digestion in which the biodegradable material is broken down by microorganisms in the absence of oxygen. This creates a methane-rich biogas suitable for energy production and utilization in differing ways. Anaerobic digestion is a multi-stage process with the stages of hydrolysis, acidogenesis, acetogenesis and methanogenesis. Hydrolysis is the stage where the organic material or polymeric biomass like polysaccharides, proteins, and lipids (Zhongtang et al., 2010) is broken down into smaller particles such as monosaccharide, amino acids and long chain fatty acids (IWA, 2002). The second part of this process is acidogenesis where the smaller particles are fermented to short-chain fatty acids, carbon dioxide and hydrogen. During this process, some alcohols are also produced. The third stage, acetogenesis, converts these alcohol and short-chain fatty acids to acetate; hydrogen and carbon dioxide. This process requires the products to be taken away rapidly, because the reactions are actually thermodynamically not favorable. The methanogen bacteria thrive by doing just that in the last step of the process; the acetate is consumed by them and converted into methane. Thus the acetogens and methanogens live in syntrophy (Zhongtang et al., 2010).

Bangladesh has a wonderful climate for biogas production. The ideal temperature for biogas production is around $35^{\circ} \mathrm{C}$. The temperature in Bangladesh usually varies from $6^{\circ} \mathrm{C}$ to $40^{\circ} \mathrm{C}$.But the inside temperature of a biogas digester generally remains at $22^{\circ} \mathrm{C}-30^{\circ} \mathrm{C}$, which is very near to the optimum requirement (Uddin and Mojumder, 2011). Present study was focused on to identify the general physicochemical composition of household solid waste to determine the potentiality of biogas production. 


\section{Materials and Methods}

\section{Sample Collection}

To collect solid waste samples, whole year was divided into three seasons; i) dry winter (October-March) ii) humid summer (March-June) and iii) rainy season (JuneOctober). Total 72 solid waste samples were collected from Jahangirnagar University solid waste management biogas plant, Savar, Dhaka. Among 72 samples, 36 samples were collected during dry winter season, 24 samples were collected in humid summer and 12 samples were collected during rainy season.

\section{Physicochemical Analysis}

The $\mathrm{pH}$ of the solid waste samples were measured using Soil $\mathrm{pH}$ and Moisture Tester (Model DM-15), atmospheric temperature and sample temperature were measured using thermometer. Moisture content of the each sample was determined by oven drying. This test was used to determine the water content of solid waste by drying a sample to constant mass at $60^{\circ} \mathrm{Ctemperature.}$ Samples were dried in oven until they were completely dried. Initial weight of the sample (before drying) and final weight (after drying) were taken. The water content of a given sample was defined as the ratio, expressed as a percentage, of the mass of the water to the mass of the solid waste.

\section{Results and Discussion}

Sample Temperature and Biogas Production Prospect Anaerobic digestion takes place at two different temperature ranges. Mesophillic condition $\left(20-45^{\circ} \mathrm{C}\right)$ and Thermophillic condition $\left(50-65^{\circ} \mathrm{C}\right)$ (Monnet, 2003). Mesophillic bacteria have lower metabolic rates. Mesophillic digestion requires longer retention times. But they are more robust to the changes in temperature. They are able of producing good quality effluent (Ostrem, 2004). Fig. 1 shows the collected samples temperature and atmospheric temperature at different seasons. In dry winter, sample temperature varied between $27^{\circ} \mathrm{C}$ to $34.5^{\circ} \mathrm{C}$. Minimum temperature in humid summer was $27^{\circ} \mathrm{C}$ and maximum was $42.5^{\circ} \mathrm{C}$. In rainy season, sample temperature varied between $35.96^{\circ} \mathrm{C}$ and $40.56^{\circ} \mathrm{C}$. During all the seasons,

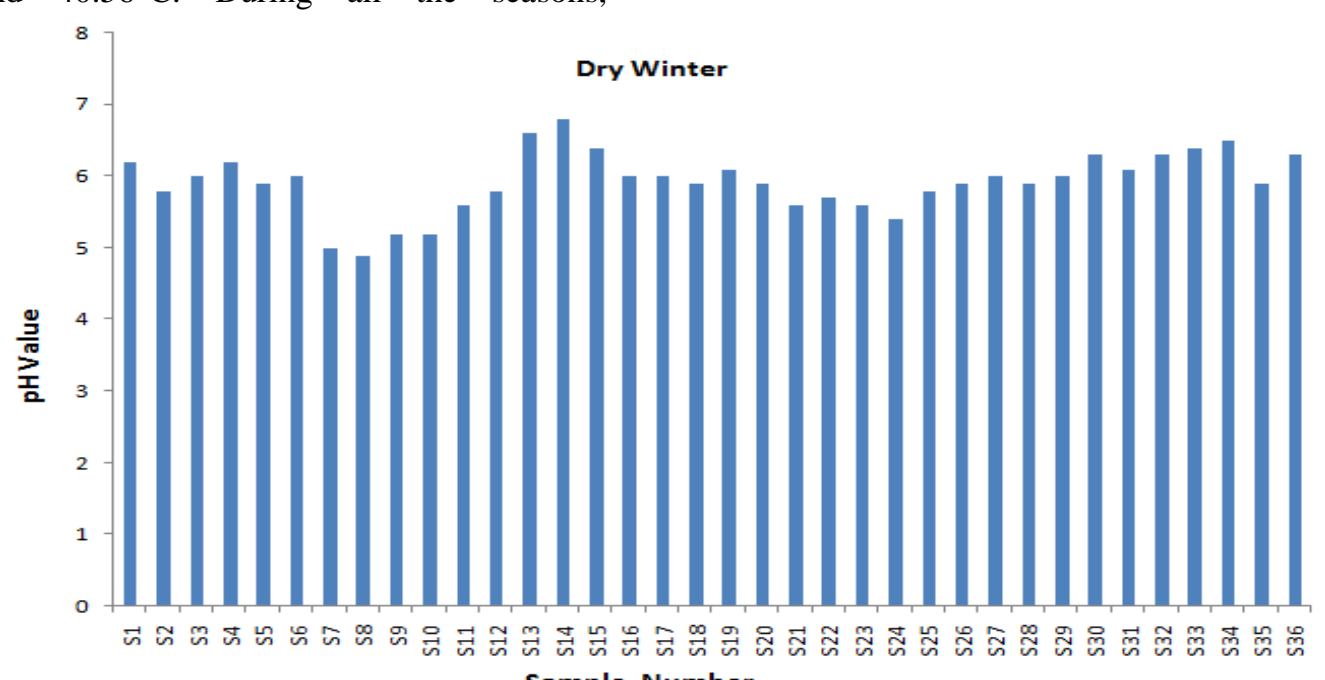

temperature ranges between $27^{\circ} \mathrm{C}$ to $42.5^{\circ} \mathrm{C}$ (mesophilic condition).

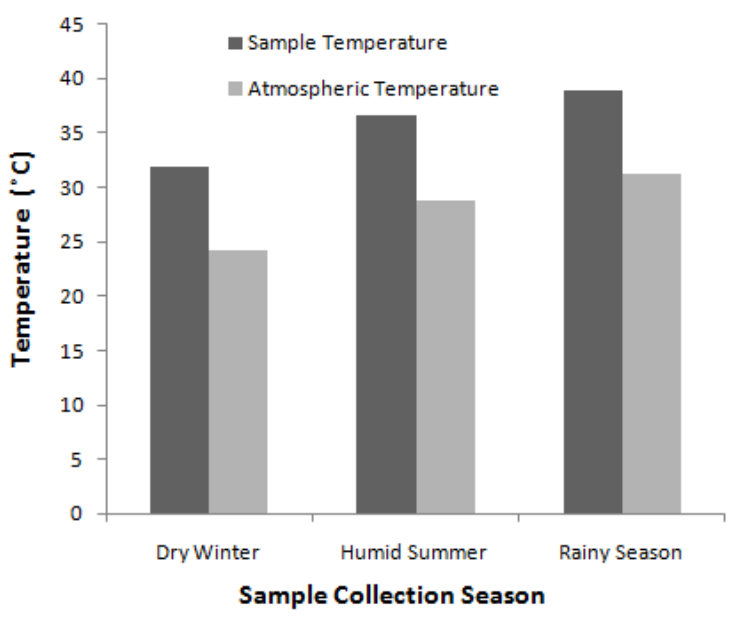

Fig. 1. Atmospheric temperature and sample temperature during various seasons

The fermentation is more efficient at the higher temperature (thermophillic condition) process (CBRI, 1992). The thermophilic regimes also carry an importance for getting rid of pathogens residing in the waste to be processed (Kim et al., 2003). Raising the temperature of solid waste during this thermophilic stage might increase the biogas production efficiency. The thermophilic condition will require more heat, requiring the use of more energy in the process. Thermophilic conditions are not as stable as in the mesophilic conditions and feeding of ill-suited material is more likely to cause more serious problems in the system (Curry and Pillay, 2012).

\section{Sample pH and Biogas Production Prospect}

The optimum $\mathrm{pH}$ values for the anaerobic digestion are in the range of $6.4-7.2$. The optimum $\mathrm{pH}$ for methanogens is 6.6-7.0 (Monnet, 2003). Growth rate of methanogenic bacteria is slower than the acidogenic bacteria.

(a) 


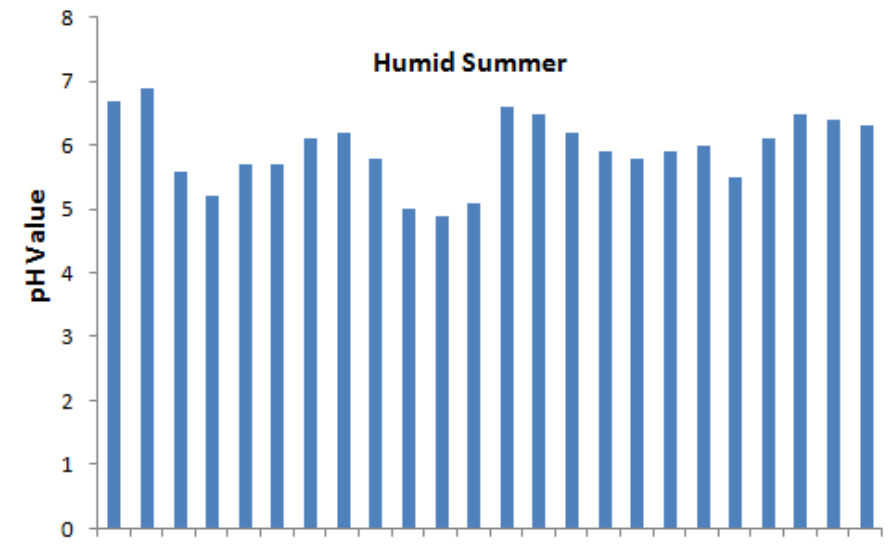

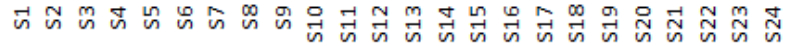
Sample Number

(b)

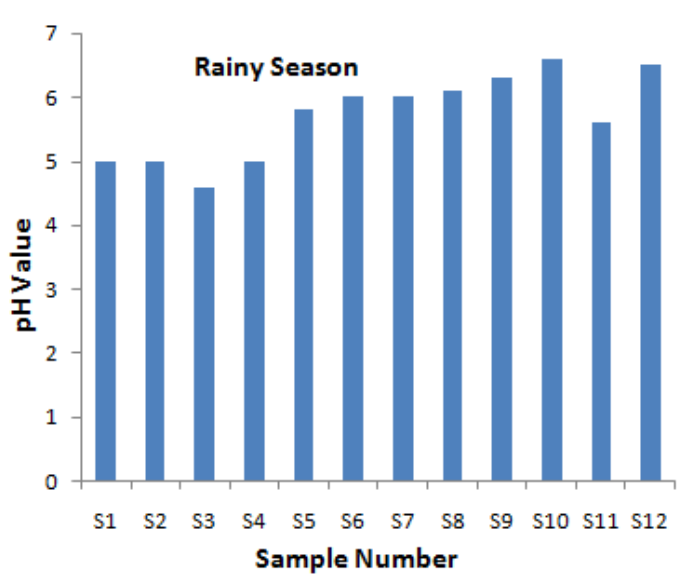

(c)

Fig. 2. The $\mathrm{pH}$ value of collected samples during various seasons

At lower $\mathrm{pH}$ values and higher feed rates the growth rate of acidogenic bacteria increases. Therefore acid formation during acidogenisis reduces the $\mathrm{pH}$ of the medium and inhibits the methanogenisis process.

Fig. 2a shows the $\mathrm{pH}$ values of the solid waste during dry winter season. The mean value was 5.92 and ranged from 4.9 to 6.8 . Most of the values were below the optimum $\mathrm{pH}$ range for anaerobic digestion which may hinder the highest gas production during this season. During humid summer season, the mean value was 5.94 and varied from 4.9 to 6.9 (Fig. 2b). Mean pH value of solid waste in rainy season was 5.81 and varied from 4.6 to 6.6 (Fig. 2c). Most of the samples collected through the year showed $\mathrm{pH}$ values which were not in optimum range for anaerobic digestion. Hence, for highest production of gas, waste media used in anaerobic digestion must have adequate buffering capacity to maintain appropriate $\mathrm{pH}$ or a buffer should be added (MSU, 2011).

\section{Sample Moisture Content and Biogas Production Prospect}

The moisture content of solid waste in Dhaka varies from $50-60 \%$ and contains high amount of carbohydrate. This implies that, biogas production from solid organic waste through anaerobic digestion would be a promising green energy source for Dhaka (Alam et al., 2001). Present study aims to provide the information about the biogas production potential from the anaerobic digestion of organic solid waste. The statistical summary of the moisture contents of collected samples in various seasons is given in Table 1.

Table 1. Statistical summary of the moisture content of collected samples in various seasons

\begin{tabular}{c|c|c|c}
\hline Statistical summery & Dry Winter & Humid Summer & Rainy Season \\
\hline Mean & 57.33 & 54.92 & 58.67 \\
\hline Maximum & 64 & 63 & 63 \\
\hline Minimum & 46 & 33 & 54 \\
\hline Median & 58 & 57 & 58.5 \\
\hline SD & 4.43 & 6.51 & 2.74 \\
\hline SE & 0.74 & 1.33 & 0.79 \\
\hline
\end{tabular}

$\mathrm{SD}=$ Standard Deviation; $\mathrm{SE}=$ Standard Error

The mean value of moisture content of solid waste in dry winter was $57.33 \%$ which indicates good prospect of biogas production. Moisture content during that season varied from $46 \%$ to $64 \%$. Mean moisture content in the solid waste during humid summer was $54.92 \%$ and varied from $33 \%$ to $63 \%$. On the other hand, the moisture content in rainy season varied from $54 \%$ to $63 \%$ whereas the average value was $58.67 \%$. Hence, in term of moisture content, there is a good prospect of biogas production from the collected solid waste samples in all seasons.

\section{Conclusions}

Production of biogas from solid waste is a good alternative strategy of solid waste management. Present study showed that, sample $\mathrm{pH}$ and temperature were not in the optimum condition for biogas production which may hamper the gas production efficiency. Proper buffering system and temperature regulation may solve this problem. Therefore, higher research is needed on the temperature and $\mathrm{pH}$ controlling systems in digester.

\section{References}

Alam, M.; Rikta, S. Y.; Hasnine, M. T.; Ahmed, F. and Kamal, A. K. I. 2016. Production of Eco-friendly Handmade Paper from the Waste Paper Generated in Municipalities of Dhaka City, Bangladesh. EurAsia Waste Management Symposium, 2-4 May, YTU 2010 Congress Center, İstanbul/Türkiye. 
Alam, M. J. and Bole, B. 2001. Energy recovery from municipal solid waste in Dhaka city. In: Proceedings of the International Conference on Mechanical Engineering, Dhaka, 26-28 December: 125-130.

Bangladesh Power Development Board (BPDB). 2008. Annual Report of 2006-2007. Dhaka, Bangladesh: BPDB. Available at: www.bpdb.gov.bd/download/Annual\%20Report10.pdf

Chengdu Biogas Research Institute (CBRI).1992. The Biogas technology in China. P.R.C., Agricultural publishing house, ISBN 7-109-01777-X/S.1174.

Curry, N. and Pillay, P. 2012. Biogas prediction and design of a food waste to energy system for the urban environment. Renewable Energy, 41: 200-209.

Islam, M. S.; Sultana, A.; Rasheduzzaman, K. M. G. K.; Kamal, A. K. I. and Uddin, M. K. 2015. Assessment of the Present State and Economical Prospects of Solid Waste at Amin Bazar Waste Dumping Site, Dhaka. Bangladesh. Journal of Scientific Research, 7(3): 129-137.

IWA. 2002. IWA task group for mathematical modelling of AD processes. AD model no.1. London, IWA.

Kim, M.; Gomec, C. Y.; Ahn, Y. and Speece, R. E. 2003. Hydrolysis and acidogenesis of particulate organic material in mesophilic and thermophilic AD. Environmental Technology, 24: 1183-1190.

Michigan State University (MSU). 2011. Biogas potential of household waste for use in high school science curriculum. Civil and Environmental Engineering, Michigan State University.
Monnet, F. 2003. An introduction to anaerobic digestion of organic wastes. Remade, Scotland.

Ostrem, K. 2004. Greening waste: Anaerobic digestion for treating the organic fraction of municipal solid wastes. Department of Earth and Environmental Engineering, $\mathrm{Fu}$ Foundation of School of Engineering and Applied Science, Columbia University.

Sarkar, S. K. and Uddin, M. K. 2011. Window of Opportunity: An Asset Based Approach to Community Development in Bangladesh. Journal of Developments in Sustainable Agriculture, 6:1-11.

Sarkar, S. K. and Uddin, M. K. 2013ª. Converting Environmental Friendly Waste into Wealth. Bangladesh Rural Development Studies, 16(1): 113128.

Sarkar, S. K. and Uddin, M. K. 2013 ${ }^{\mathrm{b}}$. Community based waste management and its utilization for sustainable environment. Bangladesh Journal of Animal Science, 42(2): 165-17.

Uddin, M. M. and Mojumder, M. S. S. 2011. Biogas production from municipal waste: Prospect in Bangladesh. Cyber Journals: Multidisciplinary Journals in Science and Technology, Journal of Selected Areas in Renewable and Sustainable Energy (JRSE).

Zhongtang, Y.; Morrison, M. and Schanbacher, F. L. 2010. Production and utilization of methane biogas as renewable fuel. Biomass to Biofuels, 20: 403- 433. 